\title{
Covering Rearing Tanks Improves Brown Trout Growth and Feed Conversion
}

\author{
Eric Krebs, Michael E. Barnes, Patrick A. Nero \\ South Dakota Department of Game, Fish and Parks, McNenny State Fish Hatchery, Spearfish, SD, USA \\ Email: mike.barnes@state.sd.us
}

How to cite this paper: Krebs, E., Barnes, M.E. and Nero, P.A. (2016) Covering Rearing Tanks Improves Brown Trout Growth and Feed Conversion. Agricultural Sciences, 7, 869-878.

http://dx.doi.org/10.4236/as.2016.712079

Received: December 1, 2016

Accepted: December 20, 2016

Published: December 23, 2016

Copyright $\odot 2016$ by authors and Scientific Research Publishing Inc. This work is licensed under the Creative Commons Attribution International License (CC BY 4.0).

http://creativecommons.org/licenses/by/4.0/

\begin{abstract}
Although an important part of the natural environment of fish, overhead cover is usually absent during hatchery rearing. To evaluate the possible influence of overhead cover on juvenile brown trout Salmo trutta hatchery rearing performance, this study compared three different cover treatments: near-full (98\%) cover, partial (65\%) cover, and no cover (completely open). After 12 weeks of rearing in $1.8 \mathrm{~m}$-diameter circular tanks, total tank weight gain was significantly greater and feed conversion ratios were significantly less in tanks of brown trout that were either partially or near-totally covered, in comparison to those tanks that were completely open. The viscerosomatic index, hepatosomatic index, and splenosomatic index values were not significantly different among any of the treatments. Fin condition indices were also not significantly different. The use of either partial or full covers is recommended to maximize brown trout rearing efficiencies, with full covers providing the additional benefit of preventing fish from jumping out of the tanks.
\end{abstract}

\section{Keywords}

Brown Trout, Overhead Cover, Salmo trutta, Circular Tanks

\section{Introduction}

Tanks used during hatchery rearing are typically uncovered to facilitate regular cleaning, allow for observations on fish growth, and discover possible fish health issues [1] [2] [3]. However, overhead cover is a normal part of the natural environment of wild fish, and brown trout Salmo trutta in particular is attracted to overhead cover [4] [5].

Because overhead cover is essential in natural habitats for numerous salmonids [6] [7] [8] [9] [10], studies have been conducted evaluating the use of partial covers during hatchery rearing. In some studies, partial overhead tank covers have improved the hatchery rearing performance of rainbow trout Oncorhynchus mykiss [11] [12] and brown 
trout [13]. However, the benefits of partial tank covers have not been universally reported, and may be species or strain specific [14] [15] [16] [17].

The concept of overhead cover was recently expanded to include covering nearly the entire top of the tank during the rearing of rainbow trout [12]. These nearly-full covers, with only a small open space to allow automatic feeders to dispense food to the fish, produced rainbow trout rearing performance superior to uncovered tanks and similar to that observed in partially-covered tanks [12]. In the only other study involving neartotal tank covers during salmonid rearing, Roadhouse et al. observed that lake trout Salvelinus namaycush was significantly heavier when reared in covered troughs compared to those reared in uncovered troughs [18].

There have been no published studies examining the use of near-full covers during the hatchery rearing of brown trout. Thus, the objective of this study was to investigate the use of near-total tank covers on the growth and feeding efficiency of brown trout in comparison to those reared with partial covers or no overhead cover at all.

\section{Materials and Methods}

\subsection{Hatchery Rearing}

Experimentation occurred at McNenny State Fish Hatchery, rural Spearfish, South Dakota, USA using twelve circular fiberglass tanks $(1.8 \mathrm{~m}$ in diameter, $0.8 \mathrm{~m}$ deep, $0.6 \mathrm{~m}$ operating depth). Each tank received approximately $45 \mathrm{~L} / \mathrm{min}$ of aerated and degassed well water $\left(11^{\circ} \mathrm{C}\right.$; water hardness as $\mathrm{CaCO}_{3}-360 \mathrm{mg} / \mathrm{L}$; alkalinity as $\mathrm{CaCO}_{3}-210 \mathrm{mg} / \mathrm{L}$; $\mathrm{pH}-7.6$; total dissolved solids-390 $\mathrm{mg} / \mathrm{L}$ ). Three overhead tank cover treatments were used $(\mathrm{N}=4)$ : open (no cover), partial cover over $65 \%$ of the tank, and near-full cover over $98 \%$ of the tank (with a small opening for the automatic feeder). Partial and near-total covers were made by riveting $6.35 \mathrm{~mm}$ corrugated black plastic sheeting (Coroplast, Vanceburg, Kentucky, USA), which was cut into a semi-circular shape to match the diameter of the open tops of the rearing tank, onto square aluminum tubing at the radius (Figure 1). The size of the partial cover was due to the use one $1.22 \times$ $2.44 \mathrm{~m}$ corrugated plastic sheet for each partial cover during construction. Ambient lighting occurred because of $0.5 \mathrm{~m}$ high translucent panels located just below the tank room ceiling, with daylight ranging from approximately $14.1 \mathrm{~h}$ at the start of the study to $15.2 \mathrm{~h}$ at the end. Overhead electric lights were only turned on once a day for approximately 15 min during daily tank cleaning and mortality removal.

The study began on April 29, 2015 and lasted for 12 weeks. At the start of the experiment, each of the twelve tanks received $10.23 \mathrm{~kg}$ (approximately $1650 \mathrm{fish}$ ) of juvenile Plymouth Rock strain brown trout [Mean (SE) weight and length of 6.17 (0.18) g and $80.8(0.8) \mathrm{mm}$, respectively]. Fish were fed $1.5 \mathrm{~mm}$ extruded, floating pellets (Skretting, Tooele, Utah, USA) to satiation daily, which was based on a hatchery constant of 7.26 $(0.065 \mathrm{~mm} /$ day) with an anticipated 1.1 feed conversion [19]. Feeding to satiation was visually verified at periodic intervals, and individual lengths and weights of fish from each tank were measured approximately every 30 days to evaluate feeding rates and growth projections ( $\mathrm{n}=5$ on day 30 and 62 ). Each tank received $23.35 \mathrm{~kg}$ of feed during 


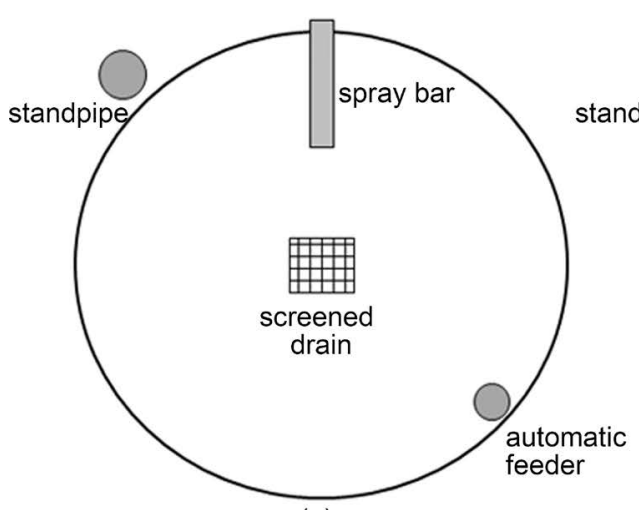

(a)

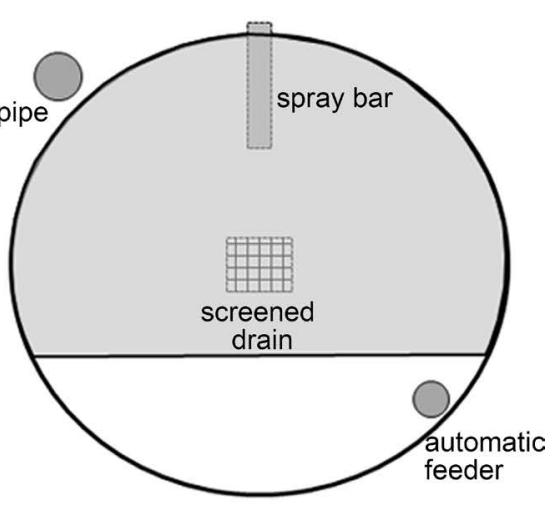

(b)

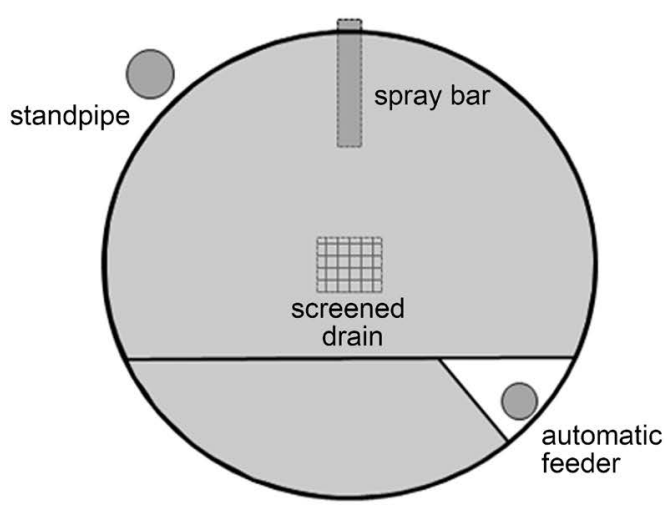

(c)

Figure 1. Schematics of an uncovered tank (a), partially covered tank (b), and near fully covered $\operatorname{tank}(\mathrm{c})$.

the experiment. Pellets were dispensed from EWOS 505 (Norco-last AS, Sweden) automatic feeders between 08:00 to 18:00 for 1 minute at 20-minute intervals. Feed rations, along with the number and weight $(\mathrm{g})$ of mortalities, were recorded daily for each tank.

\subsection{Data Collection}

Total body weights to the nearest $0.1 \mathrm{~g}$, and viscera, liver, and spleen weights to the nearest $0.001 \mathrm{~g}$, were recorded at the beginning of the experiment from a common pool $(n=30)$ and at the end of the experiment from each tank using a model ER-120A A\&D electronic balance (Tokyo, Japan). Digital calipers were used to record total lengths, and the lengths of the dorsal fin and one pectoral and pelvic fin to the nearest $0.01 \mathrm{~mm}$. Additionally, total tank biomass (to the nearest $5 \mathrm{~g}$ ) was measured at the beginning and end of the experiment for each tank using a Ohaus model T1XW scale (Parsippany, New Jersey, USA). At the end of the experiment, total body, liver, spleen and visceral weights were recorded from five randomly-selected individuals from each tank. Total, dorsal, pectoral and pelvic fin lengths were also recorded for the same individual fish.

The following equations were used:

1) Condition Factor $(\mathrm{K})=\left[\right.$ weight $(\mathrm{g}) /$ total length $\left.(\mathrm{cm})^{3}\right] \times 100$. 
2) Fin index $(\%)=\{[$ fin length $(\mathrm{mm}) \div$ total length $(\mathrm{mm})] \times 100\}$.

3) Viscerosomatic index $($ VSI $)=\{[$ weight of viscera $(\mathrm{g}) \div$ total fish weight $(\mathrm{g})] \times$ $100\}$.

4) Hepatosomatic index $(\mathrm{HSI})=\{[$ liver weight $(\mathrm{g}) \div$ total fish weight $(\mathrm{g})] \times 100\}$.

5) Splenosomatic index $(\mathrm{SSI})=\{$ [spleen weight $(\mathrm{g}) \div$ total fish weight $(\mathrm{g})] \times 100\}$.

6) Food conversion ratio $(\mathrm{FCR})=$ feed fed $(\mathrm{g}) /$ weight gain $(\mathrm{g})$.

\subsection{Statistical Analysis}

Data were analyzed using the SPSS (9.0) statistical analysis program (SPSS, Chicago, Illinois, USA) with significance predetermined at $\mathrm{P}<0.05$. Individual tanks were the replicates used for statistical analysis because they were the experimental unit, not the individual fish. At the end of the experiment when multiple fish were sampled from one tank, the mean of that sample was considered a replicate and used for analysis. One way analysis of variance (ANOVA) was conducted, and if the treatments were significantly different, pairwise mean comparisons were performed using the Tukey HSD test.

\section{Results}

Total tank weight gain and food conversion ratio were significantly improved in tanks that were either near-completely covered or partially covered, compared to uncovered tanks (Table 1). However, no significant differences in growth or food conversion ratio were found between the near-completely covered and partially covered tanks. Mortality was under $0.5 \%$ in all of the tanks and was not significantly different among the treatments.

No significant differences were observed among the treatments in individual fish lengths (Table 2). Mean individual fish weights were $18.3 \mathrm{~g}, 16.3 \mathrm{~g}$, and $16.3 \mathrm{~g}$ in the near-completely covered, partially covered, and uncovered tanks, respectively, but were not significantly different. There was no significant difference in any of the internal organ indices. Mean SSI was 0.19 in the uncovered tanks compared to 0.10 and 0.09 in the covered tanks but, there was considerable variation. There was no significant difference in fin condition indices among the treatments as well.

Table 1. Mean (SE) rearing data for tanks of rainbow trout that were open at the top, partially-covered, or near-fully covered. Means in a row with different letters are significantly different $(\mathrm{N}=4, \mathrm{P}<0.05)$.

\begin{tabular}{|c|c|c|c|c|}
\hline & \multicolumn{3}{|c|}{ Rearing Tank Cover } & \multirow[b]{2}{*}{$\mathrm{P}$ value } \\
\hline & None & Partial & Near-Full & \\
\hline Start weight $(\mathrm{kg})$ & $10.23 \pm 0.00$ & $10.23 \pm 0.00$ & $10.23 \pm 0.00$ & \\
\hline Food fed (kg) & $23.35 \pm 0.00$ & $23.35 \pm 0.00$ & $23.35 \pm 0.00$ & \\
\hline End weight (kg) & $27.00 \pm 0.43 \mathrm{z}$ & $28.54 \pm 0.19 y$ & $28.83 \pm 0.09 y$ & 0.002 \\
\hline Gain (kg) & $16.77 \pm 0.43 \mathrm{z}$ & $18.31 \pm 0.19 y$ & $18.61 \pm 0.09 y$ & 0.002 \\
\hline Food Conversion Ratio & $1.40 \pm 0.04 \mathrm{z}$ & $1.28 \pm 0.13 \mathrm{y}$ & $1.26 \pm 0.06 y$ & 0.004 \\
\hline Mortality (\%) & $0.31 \pm 0.07$ & $0.16 \pm 0.04$ & $0.22 \pm 0.07$ & 0.258 \\
\hline
\end{tabular}


Table 2. Ending mean (SE) length, weight, condition factor $(\mathrm{K})^{\mathrm{a}}$, liver weight, hepatosomatic index $(\mathrm{HSI})^{\mathrm{b}}$, viscera weight, viscerosomatic index (VSI) ${ }^{\mathrm{c}}$, spleen weight, splenosomatic index $(\mathrm{SSI})^{\mathrm{d}}$, fin lengths, and fin indices ${ }^{\mathrm{e}}$ from rainbow trout reared in tanks that were open at the top, partially-covered, or near-fully covered $(N=4, \mathrm{P}<0.05)$.

\begin{tabular}{ccccc}
\hline & \multicolumn{3}{c}{ Rearing Tank Cover } \\
\hline None & Partial & Near-Full & P value \\
Weight (g) & $115 \pm 2$ & $113 \pm 3$ & $118 \pm 4$ & 0.550 \\
$\mathrm{~K}^{\mathrm{a}}$ & $16.3 \pm 0.62$ & $16.3 \pm 1.3$ & $18.3 \pm 1.7$ & 0.476 \\
HSI $^{\mathrm{b}}$ & $1.05 \pm 0.03$ & $1.08 \pm 0.02$ & $1.07 \pm 0.02$ & 0.691 \\
VSI $^{\mathrm{c}}$ & $1.79 \pm 0.18$ & $1.68 \pm 0.07$ & $1.89 \pm 0.05$ & 0.483 \\
SSI $^{\mathrm{d}}$ & $8.90 \pm 0.10$ & $8.42 \pm 0.77$ & $8.65 \pm 0.54$ & 0.829 \\
Pectoral fin index & $12.44 \pm 0.15$ & $13.10 \pm 0.24$ & $12.56 \pm 0.30$ & 0.174 \\
Dorsal fin index & & $11.32 \pm 0.92$ & $10.52 \pm 0.31$ & 0.300 \\
Pelvic fin index & $11.62 \pm 0.22$ & $11.49 \pm 0.50$ & $11.45 \pm 0.40$ & 0.807 \\
\hline
\end{tabular}

${ }^{\mathrm{a}} \mathrm{K}=10^{5} \times($ weight $) /\left(\right.$ length $\left.{ }^{3}\right) ;{ }^{\mathrm{b}} \mathrm{HSI}=100 \times($ liver weight $/$ body weight $) ;{ }^{\mathrm{c}} \mathrm{VSI}=100 \times($ viscera weight $/$ body weight $) ;$ ${ }^{\mathrm{d}} \mathrm{SSI}=100 \times($ spleen weight $/$ body weight $) ;{ }^{\mathrm{e}}$ Fin index $=100 \times($ fin length $/$ total length $)$.

\section{Discussion}

\subsection{Cover}

The significant improvements with the use of either partial or near-total overhead cover observed in this study with brown trout are similar to those reported for rainbow trout [12]. Partial covers have been previously shown to improve brown trout rearing performance in circular tanks [13], but this study is the first to document the positive effects of near-total tank overhead coverage. In contrast, Pickering et al. observed no increase in brown trout growth when reared under partial covers [14]. The discrepancy between these studies may be due to the genetic strain of brown trout used in these experiments. Pickering et al. used a very domesticated strain [14], while the Barnes et al. used a very wild strain [13]. Strain differences have also been suggested to cause differences in the reaction to overhead cover in rainbow trout [12].

In the wild, brown trout have been observed to spend a large amount of time under cover, and especially use overhead cover to avoid disturbances [20] [21]. The use of overhead cover during hatchery rearing is likely accommodating brown trout innate behavior [7] [22]. By providing an area of refuge in an otherwise relatively sterile hatchery environment, overhead cover may be increasing brown trout growth by reducing the expenditure of energy and stress that occurs in uncovered tanks as the trout search in futility for a place of refuge [14] [23] [24] [25].

\subsection{Lighting}

It is also possible that the location of the tanks may have influenced the results. Pickering et al. reared brown trout and other salmonids in outdoor tanks and noticed little 
positive effect from overhead cover [14], where-as this study and others [11] [12] [13] were conducted indoors under ambient light filtering inside through translucent panels. In this study, in the near-fully covered tanks, only 0.1 lux of light was able to enter the tank through the small opening for the feeder, but apparently this small amount of light either met or exceeded the amount needed for brown trout growth [26] [27].

\subsection{Indices}

The feeding rate used for this study was based on historical data to achieve satiation and maximum growth at McNenny Hatchery. The relatively high HSI values, similar to those of similarly-sized rainbow trout fed to satiation [28] and much greater than those of trout fed restricted rations [12] [28], appear to indicate that the brown trout in this study were fed close to, or at, satiation. HSI is an indicator of liver energy content [29] and is particularly indicative of nutritional status [30]. Both HSI and VSI are indicators of lipid deposition, and the lack of differences among the treatments suggests that nutrient partitioning was similar between the covered and uncovered tanks [31] [32] [33] [34], even though growth and feed conversion were improved through the use of overhead cover.

All of the SSI values were within normal limits as reported by Shimma et al., Uyan et al., and Wiens et al. [35] [36] [37]. However, the relatively large SSI mean, although not significantly different from the covered tanks, and increased SSI variation in from fish in the open tanks is none-the-less interesting. The spleen plays a major role in trout immune responses [38], and has been shown to increase in size as a result of stress or disease [39] [40]. SSI is an indirect measure of immune function [37], and the SSI means from fish in the covered tanks were similar to that reported for unstressed salmonids in other studies [12] [28] [40]. However, the mean SSI observed in the open tanks is similar to that reported from diseased or stressed rainbow trout [40] [41].

The fin index values were generally greater than that reported previously for hatchery-reared brown trout and slightly less than that observed in wild brown trout [42]. These values may also provide additional evidence that the fish were fed to satiation in this study, because satiated fish are less aggressive and aggression is linked to decreased fin lengths [43] [44].

\subsection{Structural Advantages}

The plastic covers with aluminum supports used in this study have several ad-vantages over the wooden covers used in other studies by Barnes et al. [13]. The plastic covers are very light weight, extremely sturdy, and virtually unaffected by water. These materials do not rot or rust, as compared to covers composed of either wood or steel. The plastic covers are also much easier to remove and re-install, making fish moving and tank cleaning much less laborious.

\section{Conclusion}

In conclusion, the use of either partial or near-total overhead cover is recommended 
during the indoor rearing of brown trout in circular tanks. The use of near-total covers provides an additional benefit of keeping the trout from jumping out of the tanks, but makes tank cleaning and fish observations more difficult. In situations where frequent tank cleaning or fish observations are required, partial tank covers may be more practical.

\section{Acknowledgements}

We thank Kelby Torgerson, Jeremy Kientz, and Kati Krebs for their assistance with this study.

\section{References}

[1] Stevenson, J.P. (1980) Trout Farming Manual. Fishing News Books Limited, Farnham, Surrey, England.

[2] Piper, R.G., McElwain, I.B., Orme, L.E., McCraren, J.P., Fowler, L.G. and Leonard, J.R. (1982) Fish Hatchery Management. US Fish and Wildlife Service, Washington DC.

[3] Beitlich, J.H., Jennings, B.H., Lasee, B.A., Nelson, R.C., Ott, T.J., Whitney, J.M. and Woolley, S.K. (1995) Introduction to Fish Health Management. 2nd Edition, US Fish and Wildlife Service, Onalaska.

[4] Butler, R.L. and Hawthorne, V.N. (1968) The Reaction of Dominant Trout to Changes in Overhead Cover. Transactions of the American Fisheries Society, 97, 37-41. https://doi.org/10.1577/1548-8659(1968)97[37:TRODTT]2.0.CO;2

[5] Witzel, L.D. and MacCrimmon, H.R. (1983) Redd-Site Selection by Brook Trout and Brown Trout in Southwestern Ontario Streams. Transactions of the American Fisheries Society, 112, 760-771. https://doi.org/10.1577/1548-8659(1983)112<760:RSBBTA >2.0.CO;2

[6] Bustard, D.R. and Narver, D.W. (1975) Aspects of the Winter Ecology of Juvenile Coho Salmon (Oncorhynchus kisutch) and Steelhead Trout (Salmo gairdneri). Journal of the Fisheries Research Board of Canada, 32, 667-680. https://doi.org/10.1139/f75-086

[7] Hartzler, J.R. (1983) The Effects of Half-Log Covers on Angler Harvest and Standing Crop of Brown Trout in McMichaels Creek, Pennsylvania. North American Journal of Fisheries Management, 3, 228-238. https://doi.org/10.1577/1548-8659(1983)3<228:TEOHCO >2.0.CO;2

[8] Swales, S., Lauzier, R. and Levings, C. (1986) Winter Habitat Preferences of Juvenile Salmonids in Two Interior Rivers in British Columbia. Canadian Journal of Zoology, 64, 15061514. https://doi.org/10.1139/z86-225

[9] Smith, R. and Griffith, J. (1994) Survival of Rainbow Trout during their First Winter in the Henrys Fork of the Snake River, Idaho. Transactions of the American Fisheries Society, 123, 747-756. https://doi.org/10.1577/1548-8659(1994)123<0747:SORTDT>2.3.CO;2

[10] Keith, R., Bjornn, T., Meehan, W., Hetrick, N. and Brusven, M. (1998) Response of Juvenile Salmonids to Riparian and Instream Cover Modifications in Small Streams Flowing through Second-Growth Forests of Southeast Alaska. Transactions of the American Fisheries Society, 127, 889-907. https://doi.org/10.1577/1548-8659(1998)127<0889:ROJSTR>2.0.CO;2

[11] Barnes, M.E. and Durben, D.J. (2003) Effects of Partial Tank Covers on the Growth of Juvenile Feral Rainbow Trout during Hatchery Rearing. North American Journal of Aquaculture, 65, 344-348. https://doi.org/10.1577/C03-002

[12] Walker, L.M., Parker, T.M. and Barnes, M.E. (2016) Full and Partial Overhead Tank Cover 
improves Rainbow Trout Rearing Performance. North American Journal of Aquaculture, 78, 20-24. https://doi.org/10.1080/15222055.2015.1090504

[13] Barnes, M.E., Miller, J. and Durben, D.J. (2005) Partial Overhead Tank Cover Use during Feral Brown Trout Rearing. North American Journal of Aquaculture, 67, 319-323.

https://doi.org/10.1577/A04-060.1

[14] Pickering, A., Griffiths, R. and Pottinger, T. (1987) A Comparison of the Effects of Overhead Cover on the Growth, Survival and Haematology of Juvenile Atlantic Salmon, Salmo salar L., Brown Trout, Salmo trutta L. and Rainbow Trout, Salmo gairdneri Richardson. Aquaculture, 66, 109-124. https://doi.org/10.1016/0044-8486(87)90226-2

[15] Tabor, R.A. and Wurtsbaugh, W.A. (1991) Predation Risk and the Importance of Cover for Juvenile Rainbow Trout in Lentic Systems. Transactions of the American Fisheries Society, 120, 728-738. https://doi.org/10.1577/1548-8659(1991)120<0728:PRATIO>2.3.CO;2

[16] Wagner, E.J. and Bosakowski, T. (1994) Performance and Behavior of Rainbow Trout Reared in Covered Raceways. The Progressive Fish-Culturist, 56, 123-129. https://doi.org/10.1577/1548-8640(1994)056<0123:PABORT>2.3.CO;2

[17] Wagner, E.J., Ross, D.A., Routledge, D., Scheer, B. and Bosakowski, T. (1995) Performance and Behavior of Cutthroat Trout (Oncorhynchus clarki) Reared in Covered Raceways or Demand Fed. Aquaculture, 136, 131-140. https://doi.org/10.1016/0044-8486(95)01052-1

[18] Roadhouse, S., Saari, M.J., Roadhouse, D. and Pappas, B.A. (1986) Behavioral and Biochemical Correlates of Hatchery Rearing Methods on Lake Trout. Progressive Fish-Culturist, 48, 38-42. https://doi.org/10.1577/1548-8640(1986)48<38:BABCOH >2.0.CO;2

[19] Buterbaugh, G.L. and Willoughby, H. (1967) A Feeding Guide for Brook, Brown, and Rainbow Trout. Progressive Fish-Culturist, 29, 210-215. https://doi.org/10.1577/1548-8640(1967)29[210:AFGFBB]2.0.CO;2

[20] Hartman, G.E. (1963) Observations on the Behavior of Juvenile Brown Trout in a Stream Aquarium during Winter and Spring. Journal of the Fisheries Research Board of Canada, 20, 769-787. https://doi.org/10.1139/f63-051

[21] Bachman, R.A. (1984) Foraging Behavior of Free-Ranging Wild and Hatchery Brown Trout in a Stream. Transactions of the American Fisheries Society, 113, 1-32. https://doi.org/10.1577/1548-8659(1984)113<1:FBOFWA $>2.0 . C O ; 2$

[22] Devore, P.W. and White, R.J. (1978) Daytime Responses of Brown Trout (Salmo trutta) to Cover Stimuli in Stream Channels. Transactions of the American Fisheries Society, 107, 763-771. https://doi.org/10.1577/1548-8659(1978)107<763:DROBTS >2.0.CO;2

[23] Schreck, C.B. (1981) Stress and Compensation in Teleostean Fishes: Response to Social and Physical Factors. In: Pickering, A.D., Ed., Stress and Fish, Academic Press, London, 295321.

[24] Smith, L.S. (1991) Introduction to Fish Physiology. Argent Laboratories Press, Redmond.

[25] Pickering, A.D. (1993) Growth and Stress in Fish Production. Aquaculture, 11, 51-63. https://doi.org/10.1016/0044-8486(93)90024-S

[26] Gross, W., Roelofs, E. and Fromm, P. (1965) Influence of Photoperiod on Growth of Green Sunfish, Lepomis cyanellus. Journal of the Fisheries Research Board of Canada, 22, 13791386. https://doi.org/10.1139/f65-121

[27] Mason, E., Gallant, R. and Wood, L. (1991) Productivity Enhancement of Rainbow Trout Using Photoperiod Manipulation. Bulletin of the Aquaculture Association of Canada, 91, 44-46.

[28] Parker, T.M. and Barnes, M.E. (2015) Effects of Different Water Velocities on the Hatchery 
Rearing Performance and Recovery from Transportation of Rainbow Trout Fed Two Different Rations. Transactions of the American Fisheries Society, 144, 882-890. https://doi.org/10.1080/00028487.2015.1047533

[29] Lambert, Y. and Dutil, J.-D. (1997) Can Simple Condition Indices Be Used to Monitor and Quantify Seasonal Changes in the Energy Reserves of Cod (Gadus morhua)? Canadian Journal of Fisheries and Aquatic Sciences, 54, 104-112. https://doi.org/10.1139/f96-149

[30] Hung, S.S.O., Groff, J.M., Lutes, P.B. and Finn-Aikens, F.K. (1990) Hepatic and Intestinal Histology of Juvenile White Sturgeon Fed Different Carbohydrates. Aquaculture, 87, 349360. https://doi.org/10.1016/0044-8486(90)90072-U

[31] Oguri, M. (1985) On the Liver Tissue of Freshwater Stingrays and Balloonfish. Bulletin of the Japanese Society of Scientific Fisheries, 51, 717-720.

https://doi.org/10.2331/suisan.51.717

[32] Jobling M., Koskela, J. and Savolainen, R. (1998) Influence of Dietary Fat Level and Increased Adiposity on Growth and Fat Deposition in Rainbow Trout, Oncorhynchus mykiss (Walbaum). Aquacult Research, 29, 601-607. https://doi.org/10.1111/j.1365-2109.1998.tb01174.x

[33] Company R., Calduch-Giner, J.A., Kaushik, S. and Perez-Sanchez, J. (1999) Growth Performance and Adiposity in Gilthead Sea Bream (Sparus aurata): Risks and Benefits of High Energy Diets. Aquaculture, 171, 279-292. https://doi.org/10.1016/S0044-8486(98)00495-5

[34] Yildiz, M. (2004) The Study of Fillet Quality and Growth Performance of Rainbow Trout (Oncorhynchus mykiss) Fed with Diets Containing Different Amounts of Vitamin E. Turkish Journal of Fisheries and Aquatic Sciences, 4, 81-86.

[35] Shimma, Y., Shimnia, H. and Ikedo, K. (1982) Plasma Constiuents of 2-Year-Old Rainbow Trout Raised with Fish Meal and SCP Combined Feeds. Bulletin of the National Research Institute of Aquaculture, 3, 61-73.

[36] Uyan, O., Aral, O., Harmantepe, F.B., Uyan, S. and Erdem, M. (2007) Effect of Raw Anchovy as Wet Feed on Growth Performances and Production Cost of Rainbow Trout (Oncorhynchus mykiss) during Winter Season in the Black Sea. Journal of Fisheries Sciences, 1, 104-110.

[37] Wiens, G.D., Vallejo, R.L., Leeds, T.D., Palti, Y., Hadidi, S., Liu, S., Evenhuis, J.P., Welch, T. J. and Rexroad, C.E. (2013) Assessment of Genetic Correlation between Bacterial Coldwater Disease Resistance and Spleen Index in A Domesticated Population of Rainbow Trout: Identification of QTL on Chromosome Omy19. PLOS ONE, 8, e75749. https://doi.org/10.1371/journal.pone.0075749

[38] Hadidi, S., Glenney, G.W., Welch, T.J., Silverstein, T. and Wiens, G. D. (2008) Spleen Size Predicts Resistance of Rainbow Trout to Flavobacterium psychrophilum Challenge. Journal of Immunology, 180, 4156-4165. https://doi.org/10.4049/jimmunol.180.6.4156

[39] Hisar, O., Yanki, T. and Hisar, S.A. (2002) Clinical and Pathological Investigation of Psychrobacter immobilis Infection in Rainbow Trout (Oncorhynchus mykiss, Walbaum). Israeli Journal of Aquaculture-Bamidgeh, 54,189-196.

[40] Barnes, M.E., Brown, M.L., Bruce,T.J., Neiger, R. and Sindelar, S. (2015). Effects of a Fermented Soybean Meal Diet on Rainbow Trout Mortality and Immune Function during a Disease Outbreak. Journal of Aquaculture Feed Science and Nutrition, 7, 6-15.

[41] Urbaniak, T.J., Barnes, M.E. and Davis, J.L. (2016) Acoustic Transmitters Impact Rainbow Trout Growth in a Competitive Environment. Open Fish Science Journal, 9, 37-44. https://doi.org/10.2174/1874401X01609010037

[42] Bosakowski, T. and Wagner, E.J. (1994) Assessment of Fin Erosion by Comparison of Rela- 
tive Fin Length in Hatchery and Wild Trout in Utah. Canadian Journal of Fisheries and Aquatic Sciences, 51, 636-641. https://doi.org/10.1139/f94-064

[43] Abbott, J.C. and Dill, L.M. (1985) Patterns of Aggressive Attack in Juvenile Steelhead Trout (Salmo gairdneri). Canadian Journal of Fisheries and Aquatic Sciences, 42, 1702-1706. https://doi.org/10.1139/f85-213

[44] Bosakowski, T. and Wagner, E.J. (1994) A Survey of Trout Fin Erosion, Water Quality, and Rearing Conditions at State Fish Hatcheries in Utah. Journal of the World Aquaculture Society, 25, 308-316. https://doi.org/10.1111/j.1749-7345.1994.tb00196.x

Submit or recommend next manuscript to SCIRP and we will provide best service for you:

Accepting pre-submission inquiries through Email, Facebook, LinkedIn, Twitter, etc. A wide selection of journals (inclusive of 9 subjects, more than 200 journals)

Providing 24-hour high-quality service

User-friendly online submission system

Fair and swift peer-review system

Efficient typesetting and proofreading procedure

Display of the result of downloads and visits, as well as the number of cited articles Maximum dissemination of your research work

Submit your manuscript at: http://papersubmission.scirp.org/

Or contact as@scirp.org 